\title{
GENDER GAP IN ADMISSION PERFORMANCE UNDER COMPETITIVE PRESSURE
}

\author{
Štěpán Jurajda \\ Daniel Münich
}
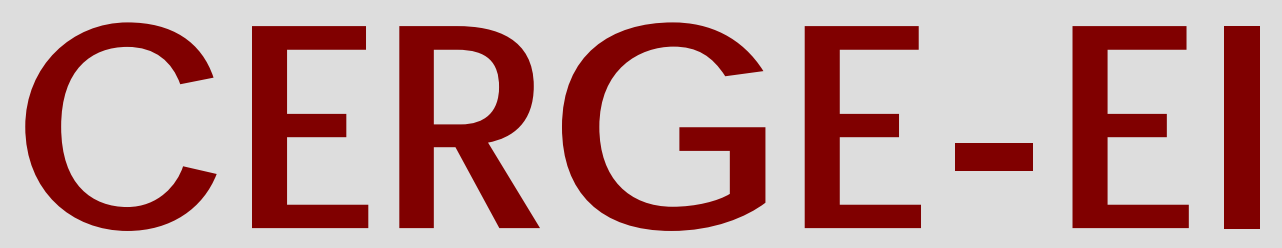

Charles University Centerfor Economic Research and Graduate Education Academy of Sciences of the Czech Republic Ec onomic s Institute 


\title{
Working Paper Series 371 (ISSN 1211-3298)
}

\section{Gender Gap in Admission Performance under Competitive Pressure}

\author{
Štěpán Jurajda
}

Daniel Münich

CERGE-EI

Prague, November 2008 
ISBN 978-80-7343-171-6 (Univerzita Karlova. Centrum pro ekonomický výzkum a doktorské studium)

ISBN 978-80-7344-160-9 (Národohospodářský ústav AV ČR, v.v.i.) 


\title{
Gender Gap in Admission Performance under Competitive Pressure
}

\author{
Štěpán Jurajda and Daniel Münich
}

\author{
CERGE-EI*
}

\begin{abstract}
Do women perform worse than equally able men in stressful competitive settings? We ask this question for competitions with a high payoff---admissions to tuition-free selective universities. With data on an entire cohort of Czech students graduating from secondary schools and applying to universities, we show that, compared to men of similar general skills and subject-of-study preferences, women do not shy away from applying to more competitive programs and perform similarly well when competition is less intense, but perform substantially worse (are less likely to be admitted) when applying to very selective universities. This comparison holds even when controlling for unobservable skills.
\end{abstract}

\begin{abstract}
Abstrakt
Dosahují ženy ve stresujících a konkurenčních situacích horších výsledků v testech než stejně schopní muži? Na základě údajů o celé kohortě českých absolventů maturitních oborů, kteří se hlásili na vysoké školy ukazujeme, že ženy, po stránce obecných intelektuálních schopností a preferencí studijních oborů srovnatelné s muži, dosahují pod slabým konkurenčním tlakem stejných výsledků v testech jako muži. Avšak v případě konkurenčního tlaku skládání přijímacích zkoušek na selektivní vysoké školy dosahují výrazně horších výsledků než muži (mají menší pravděpodobnost přijetí).
\end{abstract}

JEL Codes: J16, I29

Keywords: Gender Gap in Performance, Test Anxiety, Competition, Admissions

Acknowledgements CERGE-EI is a joint workplace of the Center for Economic Research and Graduate Education, Charles University, and the Economics Institute of the Academy of Sciences of the Czech Republic. Both authors are Research Affiliates at CEPR, London; Jurajda is also Research Fellow at IZA, Bonn. The help of Petr Matějů and Jindřich Krejčí from the Sociological Institute of the Czech Academy of Sciences and Vladimír Burda (formerly of the Czech National Institute of Technical and Vocational Education) in acquiring and processing the Sonda Maturant data is gratefully acknowledged, as are comments from Alena Bičáková and Andreas Ortmann.

Address: CERGE-EI, Charles University Prague and Academy of Sciences of the Czech Republic, Politickych veznu 7, PO BOX 882, Prague 111 21, Czech Republic.

E-mail: stepan.jurajda@cerge-ei.cz,daniel.munich@cerge-ei.cz 


\section{Introduction}

Field observations as well as experimental data have recently been used to suggest that psychological explanations are important for the persistent gender gaps in wages and representation in high-powered positions. In their book, Babcock and Laschever (2003) argue that women do not negotiate as toughly as men on salary issues because they tend to have a lower opinion of themselves than men. Women also tend to report higher levels of exam anxiety in educational psychology studies (e.g., Bors, Vigneau and Kronlundet, 2006). Experimental evidence points in a similar direction. Gneezy, Niederle, and Rustichini (2003) suggest that women are less effective than men in competitive environments, even if they perform similarly well in non-competitive settings. Niederle and Vesterlund (2007) and Datta Gupta, Poulsen and Villeval (2005) imply that men are more likely to select into a competitive environment (a tournament) than women of the same ability. Gender competition performance gaps could help explain the near absence of women from top-level managerial positions, which are awarded in repeated tournaments. ${ }^{1}$

These psychological explanations are increasingly being tested with field data (e.g., Manning and Swaffield, 2008; Lavy, 2008). In particular, the competitive nature of the education process offers several testing opportunities. Price (2008) suggests that a competitive graduate fellowship program, which aimed at increasing graduation rates, helped men on average, but benefited women only when a larger fraction of the group was female. Örs, Palomino and Peyrache (2008) also study educational outcomes within a specific group - applicants to a top-ranked French business school. They show that within this group, women outperform their male colleagues in non-competitive comprehensive tests, but lag behind men in the highly competitive school admission process. The written admission tests are graded

\footnotetext{
${ }^{1}$ For an overview of gender gaps in the labor market, see Altonji and Blank (1999). Focusing on the Czech Republic - the country of analysis in this paper - Jurajda and Paligorova (2006) show that the recent share of females among the highest-paid Czech managers is about 9\%, quite similar to the $6 \%$ Bell (2005) reports for a sample of (much larger) US firms.
} 
anonymously such that discrimination is ruled out as a potential explanation for the gender performance gap under competition. ${ }^{2}$

In this paper, we perform a similar analysis. Instead of analyzing the admission process to one very selective business school, we study the experience of an entire cohort of Czech secondary-school graduates applying to all available universities. For all applicants, we observe their test scores from a national non-competitive comprehensive examination conducted shortly before the university admission process, and we see which universities they apply to, together with the admission decision. Unlike the existing research, we can therefore compare the performance of equally able women and men under a varying degree of competition-in university admissions characterized by a varying over-subscription rate. We first ask whether a female applicant to a given university performs differently in comparison to an equally gifted male applicant, as measured by the comprehensive high-school exam. Next, we ask whether the size of such a gender performance gap depends on how selective a given admission process is - on the degree of competition. For students applying to several universities, we can also control for their unobservable ability using a person fixed effect. Finally, we also measure gender differences in aspirations, that is the difference in the selectivity of tertiary schools to which equally able men and women apply.

The Czech university admission system provides a useful framework for the study of gender performance gaps for two reasons. First, student rationing is extensive. At $12 \%$, the country has one of the lowest tertiary attainment rates in the OECD (OECD, 2004); not surprisingly, the Czech Republic features one of the highest college/high-school wage gaps in the EU (Jurajda, 2005). Tuition-free public universities provide the bulk of tertiary education, and they tend to reject about a half of the applicants each year. In 1999 - the year

\footnotetext{
${ }^{2}$ Several earlier studies, e.g., Bridgeman and Lewis (1996), document the existence of gender gaps in academic performance; however, this line of work does not ask about the effect of competitive pressure on the size of this gap. See also Nekby, Skogman Thoursie and Vahtrik (2008) for a test of gender differences in competitiveness in a male-dominated environment.
} 
our data come from - $55 \%$ of all applicants to Czech universities were not able to enroll in any program. Second, there is unique administrative data available on study achievement and university admission experience of the whole population of Czech secondary-school graduates in 1999. We work with the registry of all university applications, which tells us whether they resulted in the offer of admission, and merge it with data on all students graduating from Czech secondary schools in 1999. For these graduates, we observe national schoolleaving-exam test scores from mathematics and the native Czech. The 1999 national test of secondary-school graduates was used to evaluate schools, but had no impact on individual student grades in secondary schools or on university admissions. Using this data, we compare admission performance of similar men and women. We use the non-competitive test scores to capture students' general skills, and we also control for the overall university admission probability from a given secondary school, which captures secondary school quality.

Even with such rich data, students' subject-specific and university-specific skills remain unobservable to us. In the presence of gender preferences for certain subjects of study, ${ }^{3}$ women (men) applying to highly 'male' ('female') university programs are likely to have unusually strong program-specific skills, particularly so if they apply to very selective programs. Such selection on unobservables may therefore obscure our measurement of competition performance gaps among equally qualified applicants. We minimize the influence of gender differences in program-specific unobservables by focusing on gender-balanced pools of applicants and we also compare the performance of men and women who wish to study the same subject (field), i.e., we control for subject-of-study preferences. In a sub-set of our analysis, we extend the literature by fully controlling for individual ability, both general and subject-specific, using a person fixed effect. This is possible for the sub-set of applications where a student applies to several university programs of the same subject-of-study type that differ in their overall admission probability. Finally, we also separately examine the groups

\footnotetext{
${ }^{3}$ See Machin and Puhani (2003) for evidence on these differences from Germany and the UK and Jurajda and Franta (2007) for findings from the Czech Republic.
} 
of most and least able applicants as test anxiety may be stronger and gender competition performance gaps may be wider among weaker applicants.

We find that compared to men of similar general skills and subject-of-study preferences, women do not shy away from applying to more competitive programs. We also find that those women who do apply to very selective tertiary programs perform substantially less well (are less likely to be admitted) compared to equally able male applicants. The size of the gender admission gap increases with the degree of competition at (selectivity of) a given university program. This finding is consistent with women performing poorly under the stress of competitive, relative ranking.

Unfortunately, we do not know which universities grade their entrance exams anonymously, which prevents us from effectively disentangling gender discrimination in grading proportional to excess demand from gender differences in performance under competitive pressure as the source of the observed gender admission gaps. However, our estimates change little when we focus on gender-balanced pools of applicants, where gender stereotyping in admission may be expected to be unimportant. Furthermore, the magnitude of our estimates is in line with the effect Örs et al. (2008) estimate using one university, where they know grading is anonymous, i.e., discrimination-free.

\section{The Czech Education System and our Data}

In this section, we describe our data in more detail and use them to offer several stylized facts about the Czech education system. ${ }^{4}$ We merge university applications with test scores from a national school-leaving comprehensive examination, 'Maturita' in Czech, which is a pre-requisite for tertiary education and approximately corresponds to the U.K. General Certificate of Secondary Education or the German 'Abitur'. These exams are administered at the end of four-year secondary programs and are prepared by each school individually

\footnotetext{
${ }^{4}$ All data construction is summarized in an appendix Data Flow Chart.
} 
based on national guidelines. In 1999, however, the first (and so far the last) national 'Maturita' exam was administered on top of the school-specific exams. This national test was held simultaneously in all schools, independently of the school's own examinations, and the results were processed centrally.

The 1999 national exam covered all 'Maturita' students, i.e., approximately 60 percent of the entire cohort of 18-year olds: over one hundred thousand students in 1,642 schools. ${ }^{5}$ We observe standardized test scores (on a 0 to 100 scale) corresponding to the students' mathematics skills and to their command of native Czech as well as one foreign language. The tested students come from two main types of Czech secondary 4-year programs: vocational and academic. Vocational programs typically provide specialized training in, for example, construction or nursing, and some cover craft skills. The academic programs are typically strong in both humanities and mathematics. ${ }^{6}$

A sub-set of students graduating with the 'Maturita' exam applies to universities. We have merged their 'Maturita' test scores with the administrative register of applications to Czech universities. ${ }^{7}$ We work with a sub-set of the tested group of 105,979 secondary-school graduates, who chose to apply to at least one university program in 1999. There are 41,486 such graduates who, on average, submit about 3 university applications, resulting in a total of 116,479 applications to 116 distinct faculties of Czech universities. Fifty-five percent of all 'Maturita' students are women. This changes little, to $53 \%$, when we focus on the sub-set of university applicants. The average (as well as the standard deviation of the) number of

\footnotetext{
${ }^{5}$ There are also apprenticeship programs, which do not lead to the 'Maturita' exam; with minor exceptions, apprentices do not apply to universities. In terms of the OECD classification of education levels, the apprenticeship programs without a 'Maturita' exam correspond to the ISCED 2 level. Secondary-school education with 'Maturita' then correspond to ISCED 3A. All students taking the 'Maturita' exam have completed at least 12 years of education.

${ }^{6}$ See Filer and Münich (2000) for a detailed description of the Czech education system.

${ }^{7}$ All of the universities are public and tuition-free. Enrollment in private colleges emerged only after 1999. Even today, private tuition-based tertiary education remains miniscule in the Czech Republic.
} 
applications submitted by female and male applicants is also very similar.

We analyze the admission performance of university applicants who have graduated from secondary programs in 1999 for whom we have available 'Maturita' scores and omit applicants who have completed secondary education before 1999. Applications by "fresh" 1999 secondary-school graduates constitute $55 \%$ of all applications and $61 \%$ of university admissions in 1999. However, we use all applicants, "fresh" as well as "old", to measure the degree of competition, i.e., the admission rate of university programs. Each university program selects its students in a separate competition. Universities are tuition-free, and there are strict quotas on total enrollment at each university faculty set by the Ministry of Education; ${ }^{8}$ as a result, the average probability that a given application will result in an offer of admission is only 0.29 .

Shifting attention from applicants to universities and looking across the 116 university faculties (programs) that our data distinguish, the fraction of applications admitted varies substantially around the faculty-distribution median of 0.28 and a mean of 0.34 (with a standard deviation of 0.21 ), but is fairly low even at the 90th percentile of average facultylevel admission probability, which equals 0.60 . Hence, all universities are highly selective.

The gender composition of the pool of applicants also varies widely across university faculties (with a standard deviation of 0.24 ). There are $13 \%(78 \%)$ of female applicants for the program that is at the 10th (90th) percentile of the 'female-share' school distribution. We consider a program to be 'gender balanced' in terms of its pool of applicants if the share of women is between the 25th and 75th percentile of the school-specific distribution of applicants' 'female-ness'; this confines our analysis to schools where the 'female-ness' of applicants ranges from 40 to $69 \%$. The average admission rate in this 'balanced' sub-set of schools is similar (at 0.32 ) to the overall admission rate.

In Table 1, we present the 'Maturita', non-competitive test scores from mathematics and

\footnotetext{
${ }^{8}$ In fact, universities are financially penalized for each additional student enrolled beyond the quota limit.
} 
the Czech language for our 41,486 university applicants. The table supports the typical ordering of study achievement with academic programs outperforming the vocational ones, even conditional on applying to a university program. Students graduating from academic programs also have much higher chances of being admitted to universities. There are typical gender differences in average performance within school types. Men outperform women on math tests, while women do somewhat better on Czech-language tests (Guiso et al., 2008).

There are also large within-school-type gender gaps in the share of university applicants who are able to enter at least one university. It is not our aim to explain these gaps in access to any college, which could be the consequence of gender differences in application strategies, subject-of-study preferences, university entrance exam performance, or selection into applicant status. Our main question is a narrow one: we ask whether the size of the admission-probability gender gap among applicants with similar 'Maturita' test scores depends on the selectivity of the program to which they are applying. Nevertheless, we need to understand the main sources of the overall gender admission gaps in order to proceed to our narrow question. We therefore estimated three preliminary least-squares regressions predicting application success using all 116,479 applications. (We ask about the admission probability of an application, not that of an applicant.) Conditioning only on the female dummy and secondary-school type, we obtain a female-dummy coefficient, a measure of the overall admission gender gap, of -0.13 . Conditioning further on the 'Maturita' test scores and the average success rate of a given secondary school, brings the female-dummy parameter down to $-0.10 .^{9}$ Finally, conditioning additionally on eight subject-of-study types of university programs ${ }^{10}$ reduces the female-dummy coefficient to -0.02. A gender gap in admission probability of a mere two percentage points may in part be related to a gender competition-

\footnotetext{
${ }^{9}$ Needless to say given the sample size, all of the female-dummy coefficients are highly statistically significant. We obtain similar results using the Probit model.

${ }^{10}$ Medicine, humanities, natural sciences, technical (engineering), agriculture, arts, informatics, and pedagogy.
} 
performance penalty that we test for below. It is clear, however, that subject-of-study choice is a major gender-related determinant of admission chances; hence, all of our subsequent analysis will condition on this field choice.

\section{Aspiration Analysis}

Our first question is whether among university applicants of similar ability, men chose more competitive universities to apply to, i.e., university programs with a lower admission rate. If so, women would be on average more able within the group of applicants to highly selective universities. To generate an answer that is not influenced by gender preferences in subjects of study or selection on unobservable skills, we ask this question conditional on eight types of university-program subjects of study, and we also focus only on programs where the gender composition of applicants is balanced (see the previous section for the definition of 'gender balanced' and for the study-field types).

Specifically, we use application data to regress the overall admission rate at the university program targeted by a given application on applicants' gender, secondary-school type and 'Maturita' test scores and on the subject of study at the university program. We find statistically significant, but negligible conditional gender gaps in the admission rates of programs that students apply to. Table 2 bears out this claim. Irrespective of whether we use all applications or focus on those to 'gender-balanced' programs and irrespective of whether we use data on most or least able applicants, we find that, compared to similar men, women apply to university programs that are less than one percentage point different in their admission rates. (Recall that the standard deviation of school admission rates is 21 percentage points.) Women therefore appear not to shy away from competition relative to men, conditional on field choice; they do not appear to reflect any potential competition performance gap in their application strategies. ${ }^{11}$

\footnotetext{
${ }^{11}$ This conclusion rests heavily on comparing men and women with the same subject-of-study preferences.
} 


\section{College Admissions}

In this section, we ask whether women perform worse in university admissions compared to men of similar ability, as measured by 'Maturita' test scores and the secondary-school-specific average university admission rate. To ascertain how such gender performance gap depends on the degree of competition, i.e., the university admission rate, we group the application data by the quartile of the school-specific admission rate distribution and estimate leastsquares admission regressions within each group. ${ }^{12}$ To assess potential biases from selection on unobservable skills or gender stereotyping in admission-exam grading, we compare results based on all applications to those estimated off of applications to 'gender-balanced' university programs (see Section 2 for definition). To find out whether gender gaps in performance are present in different parts of the ability distribution, we also separately estimate the (binary) admission regressions for the most and least able applicants.

Table 3 lists least-squares female-dummy coefficients from admission regressions conditioning on both the Czech and the math 'Maturita' test score, the secondary-school type, the average success rate of students from a given secondary school in admissions, and a full set of dummy variables for the subject-of-study of university programs. ${ }^{13}$ There are large and statistically significant gender gaps in favour of male admission for university programs with low admission rates, i.e., for very competitive programs. The negative gender gap of about 3 to 4 percentage points that we estimate for the most competitive college admissions, based on both all applications (in column 1) and only on those to 'gender-balanced' programs (in column 2), suggests that women are significantly disadvantaged in their access to selective schools. In order to compensate for this gender competition performance gap, a

Excluding the eight university type dummies from the regression reported in the first column of Table 2 would result in a ten-fold increase in the size of the female-dummy coefficient.

${ }^{12}$ The admission-rate quartiles are based on all schools. The results are not materially affected when we group university programs into quartiles separately for each subject of study.

${ }^{13}$ We obtain fully similar findings when using the Probit model in place of the linear probability model. 
female applicant would have to improve her 'Maturita' math test score by one standard deviation. ${ }^{14}$ The small difference between results based on all applications and those based on only 'gender-balanced' programs suggests that the effect of selection based on unobservable ability differences is small or balanced with respect to highly 'female' and highly 'male' types of programs. Similarly, the negligible sensitivity is consistent with either small or balanced effects of gender stereotyping on admissions.

Next, we re-estimate the admission regressions on the sub-sets of the most and least able applicants in columns (3) and (4). The top-ability group consists of those who score above the 75th all-applicant percentile in either math or the Czech tests (or both), and the bottomability group scores below the 25 th percentile in at least one of the two tests. ${ }^{15}$ Using these two groups, we obtain results that are fully consistent with those presented in columns (1) and (2). Women appear to perform worse at the most selective programs and not elsewhere even when the gender comparison is based on the most and the least able group of applicants.

In Table 4, we repeat the comparisons of admission chances of equally able men and women from Table 3, but instead of relying on least-squares regressions, with all of their implicit functional form and weighting assumptions, we conduct a matching comparison. Specifically, we perform one-to-one nearest neighbor propensity score matching without replacement. ${ }^{16}$ The matching-based results confirm the least-squares-based findings of a significant 'female competition penalty' in admissions. The only exception is the rather small

\footnotetext{
${ }^{14}$ This comparison is based on the highly precisely estimated coefficient on the math test score (of 0.002) from an admission regression controlling for gender, 'Maturita' test scores, secondary-school type, and average secondary-school success rate and based on all 36,566 university applications to the most selective quartile of universities.

${ }^{15}$ In our admission regressions, both the mathematics and the Czech 'Maturita' test scores are invariably positively and statistically significantly related to admission chances.

${ }^{16}$ Matching is implemented in Stata 9 using the psmatch2 code. The number of observations (N) provided in Table 4 corresponds to the number of matched observations on the common support. Bootstrapped standard errors allow for clustering at the applicant level.
} 
group of (matched) bottom-ability applicants, where estimates are small and noisy.

To visualize the underlying relationship, and to free up the assumption of Table 3 of similar 'returns' to mathematics and Czech language skills across admissions to different schools, we also estimate the (least-squares) female dummy coefficient (from regressions conditioning on student ability and secondary-school type) separately for each university admission process. The results are presented in Figure 1, which plots the estimated school-specific conditional female admission gap (based on comparing similarly skilled men and women within each admission process) against the school-specific admission rate (degree of competition). Each program-specific female dummy coefficient is weighted by the inverse of its variance. ${ }^{17}$ As with the application-level analysis, we find that the female performance gap is less negative in schools with higher admission rates, i.e., lower degree of competition. The weighted-least-squares regression slope implied by Figure 1 is $0.11(0.08)$ when based on all (only 'gender balanced') university admissions. Increasing the admission rate by one standard deviation of the school-specific distribution (0.21) lowers the female competition performance gap in admission probability by over 2 percentage points - roughly the size of the overall least-squares conditional gender gap in admissions presented in Section 2.

Finally, our data also allow us to fully control for individual ability, both general and subject-specific. Secondary-school graduates submit several university applications, often to schools of the same field type. We can therefore compare admission probability of the same individual across several university programs characterized by varying admission rates. In order to make sure that we control not only for general individual ability, but also for subject-of-study ability of a given individual, we estimate admission regressions controlling for person-school-type fixed effects. In other words, we only compare admission probabilities within groups of applications by the same person to university programs of the same subject-of-study type. Specifically, using 'gender balanced' programs, we regress the bi-

\footnotetext{
${ }^{17}$ See Wooldridge (2003) for a justification of such approach based on efficiency grounds.
} 
nary admission outcome of applications on these person-school-type fixed effects and on the university overall admission rate (degree of competition). These fixed-effect regressions are estimated separately for men and for women. Clearly, an application's admission probability will increase with the school-wide admission rate; we ask whether it does so equally for men and for women. Consistent with our earlier evidence, in Table 5, we find that the competition 'gradient' of admission probability is steeper for women than for men. Women perform relatively worse than men when they face lower admission rates (higher degrees of competition). This holds also when we look separately at the group of more and less selective schools, separated by the median of the overall school admission probability. Although based only on a sub-set of applications, these results control for individual ability fully and thus effectively rule out selection on unobservable school-type ability as an explanation for our earlier findings.

\section{Conclusions}

Competition for university education is fierce in the Czech Republic and the stakes are high. We find that female applicants to university programs perform substantially less well than similar men when the admission rate is below 19\% (in the lowest quartile), but that they are similarly successful when admission rates are higher. We also find that a given woman performs relatively more poorly in more selective schools compared to the decline in admission probability across the same selectivity increase observed for a given man. Women may not be aware of such admission gender gaps as they do not seem to apply to less selective schools when compared to comparable men and when comparing within university subject-of-study groups. There is little sensitivity to using only 'gender-balanced' pools of applicants consistent with 'female competition penalty', as opposed to discrimination, being the chief mechanism underlying our estimates of performance gaps. The results are thus consistent with psychological gender differences being important for gender gaps in 
labor-market performance. Our findings are of direct import for the formation of Czech educational policies and student assistance as unequal access to quality education can have serious consequences for life-time labor market outcomes. We note here that the Czech system is typical of several other EU tertiary systems that apply school-specific selection at entry. $^{18}$

\footnotetext{
${ }^{18}$ School-specific admission standards similar to the Czech case are used in the UK, Germany and in some of the French universities. There are also countries that apply centralized selection at entry, e.g., Sweden or Denmark, and countries where access is unrestricted and where selection is applied after entry. See Jacobs and van der Ploeg (2006) and Aghion, Dewatripont, Hoxby, Mas-Colell and Sapir (2008).
} 


\section{Bibliography}

Aghion, Philippe, Dewatripont, Mathias, Hoxby, Caroline, Mas-Colell, Andreu, and André Sapir (2008) "Higher Aspirations: An Agenda for Reforming European Universities," Bruegel Blueprint Series, Vol. V.

Altonji, Joseph G., and Rebecca M. Blank (1999) "Race and Gender in the Labor Market." In Orley Ashenfelter, and David Card, Eds., Handbook of Labor Economics, Vol. 3-4, 3143-3259. Amsterdam: North Holland.

Babcock, Linda, and Sara Laschever (2003) Women Don't Ask: Negotiation and the Gender Divide, Princeton: Princeton University Press.

Bell, Linda A. (2005) "Women-Led Firms and the Gender Gap in Top Executive Jobs", IZA Discussion Paper No. 1689.

Bors, Douglas A., Vigneau, Francois, and Antonia Kronlund (2006) "Anxiety Facing Exams: Dimensionality, Similitudes and Differences in University Students," Canadian Journal of Behavioural Science 38 (2), 176 - 184.

Bridgeman, Brent, and Charles Lewis (1996) "Gender Differences in College Mathematics Grades and SAT-M Scores: A Reanalysis of Wainer and Steinberg," Journal of Educational Measurement 33 (3), 257-270.

Datta Gupta, Nabanita, Poulsen, Anders and Marie-Claire Villeval (2005) "Male and Female Competitive Behavior - Experimental Evidence," IZA Discussion Paper No. 1833.

Filer, Randal, and Daniel Münich (2000) "Responses of Private and Public Schools to Voucher Funding: The Czech and Hungarian Experience," CERGE-EI Working Paper No. 160 .

Gneezy, Uri, Muriel Niederle, and Aldo Rustichini (2003) "Performance in Competitive Environments: Gender Differences," Quarterly Journal of Economics, 118 (3), 1049 1074. 
Guiso, Luigi, Ferdinando Monte, Paola Sapienza, and Luigi Zingales (2008) "Culture, Math, and Gender," Science, 5880 .

Jacobs, Bas and Frederick van der Ploeg (2006) "Guide to Reform of Higher Education: A European Perspective" Economic Policy 21 (47), 535 - 592.

Jurajda, Štěpán (2005) "Czech Returns to Schooling: Does the Short Supply of College Education Bite?" Czech Journal of Economics and Finance 55 (1-2), pp. 83-95.

Jurajda, Štěpán, and Michal Franta (2007) "Occupational Gender Segregation in the Czech Republic," Czech Journal of Economics and Finance, 57 (5-6), 255-271.

Jurajda, Štěpán, and Teodora Paligorova (2006) "Female Managers and Their Wages in Central Europe" CERGE-EI Working Paper No. 296.

Lavy, Victor (2008) "Gender Differences in Market Competitiveness in a Real Workplace: Evidence from Performance-based Pay Tournaments among Teachers," NBER Working Paper No. 14338

Machin, Stephen, J., and Patrick A. Puhani (2003) "Subject of Degree and the Gender Wage Differential, Evidence form the UK and Germany," Economics Letters 79, 393-400.

Manning, Alan, and Joana Swaffield (2008) "The Gender Gap in Early-Career Wage Growth," Economic Journal, 118 (530), 983-1024.

Nekby, Lena, Skogman Thoursie, Peter, and Lars Vahtrik (2008) "Gender and Self-Selection into a Competitive Environment: Are Women More Overconfident than Men?" Economics Letters 100, 405-407.

Niederle, Muriel, and Lise Vesterlund (2007) "Do Women Shy Away from Competition? Do Men Compete Too Much?" Quarterly Journal of Economics, 122 (3), 1067-1101.

OECD (2004) Education at a Glance, OECD, Paris.

Örs, Evren, Frédéric Palomino, and Eloïc Peyrache (2008) "Performance Gender-Gap: Does Competition Matter?" CEPR Discussion Paper No. 6891. 
Price, Joseph (2008) "Gender Differences in the Response to Competition" Industrial and Labor Relations Review, 61 (3), 320-333.

Wooldridge, Jeffrey M. (2003) "Cluster-Sample Methods in Applied Econometrics," American Economic Review, 93 (2): 133-138. 
Figure 1: Female-Dummy Coefficients from University-Specific Least Squares Admission Regressions Controling for Ability and Secondary-School Type (Weighted by Inverse of Variance of the Dummy)

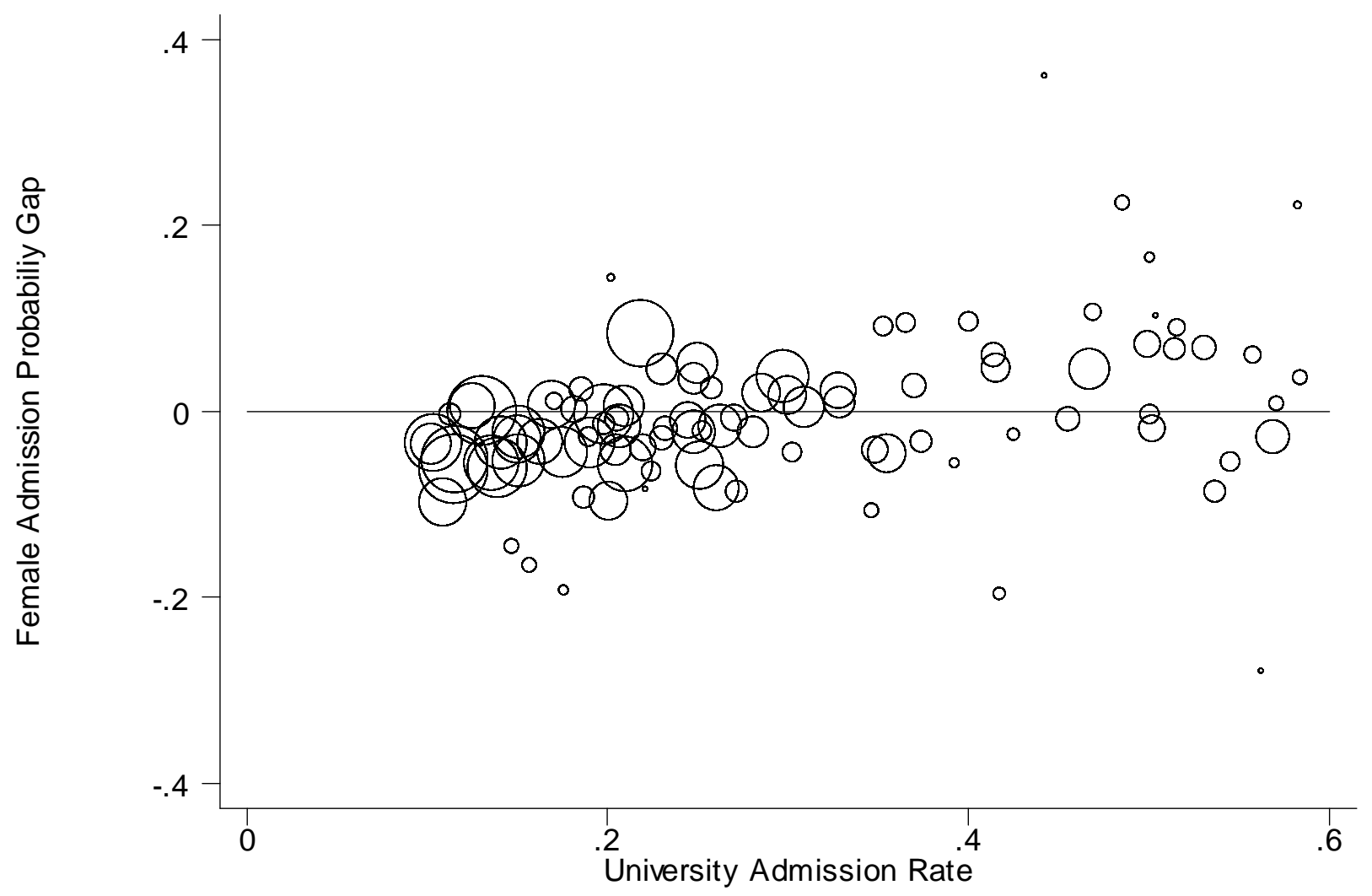


Table 1: Mean Test Scores of University Applicants by Secondary School Type

\begin{tabular}{lccccc}
\hline \hline & School Type & \multicolumn{2}{c}{ Academic } & \multicolumn{2}{c}{ Vocational } \\
& Men & Women & Men & Women \\
\hline Mathematics test score & 51.0 & 44.4 & 35.9 & 26.5 \\
& $(15.5)$ & $(15.8)$ & $(16.1)$ & $(14.6)$ \\
Czech language test score & 73.7 & 75.3 & 60.4 & 64.0 \\
& $(11.6)$ & $(11.4)$ & $(11.9)$ & $(12.0)$ \\
Share of students admitted to at least one university & 0.76 & 0.61 & 0.52 & 0.29 \\
Share of female students & & 0.57 & & 0.50 \\
& $\mathrm{~N}$ & \multicolumn{2}{c}{17,637} & & 23,849 \\
\hline \hline
\end{tabular}

Note: Standard deviations in parentheses.

Table 2: Admission Rates of Univerities Students Apply to

\begin{tabular}{|c|c|c|c|c|}
\hline Applicants & All & All & Top Ability & Bottom Ability \\
\hline \multirow[t]{2}{*}{ University programs } & All & 'Gender Balanced' & 'Gender Balanced' & 'Gender Balanced' \\
\hline & (1) & $(2)$ & $(3)$ & $(4)$ \\
\hline \multirow[t]{2}{*}{ Female } & -0.009 & 0.005 & 0.005 & 0.003 \\
\hline & $(0.001)$ & $(0.001)$ & $(0.001)$ & $(0.002)$ \\
\hline \multirow[t]{2}{*}{ Math score/100 } & -0.013 & -0.007 & -0.004 & -0.013 \\
\hline & $(0.002)$ & $(0.003)$ & $(0.005)$ & $(0.008)$ \\
\hline \multirow[t]{2}{*}{ Czech score/100 } & -0.046 & -0.019 & -0.027 & -0.005 \\
\hline & $(0.003)$ & $(0.005)$ & $(0.008)$ & $(0.010)$ \\
\hline $\mathrm{N}$ & 116,479 & 57,995 & 26,079 & 16,118 \\
\hline
\end{tabular}

Note: Robust standard errors allow for clustering at the applicant level. All regressions control for secondary school type and subject-of-study of university program. The top (bottom) ability group consists of applicants with the Math and/or the Czech 'Maturita' test scores above (below) the 75th (25th) percentile. 
Table 3: Female-Dummy Coefficients from University Admission Least-Squares Regressions

\begin{tabular}{lcccc}
\hline \hline University Programs & All & 'Gender Balanced' & All & All \\
Applicants & All & All & Top Ability & Bottom Ability \\
& $(1)$ & $(2)$ & $(3)$ & $(4)$ \\
\hline 1st Quartile of Admission Rate & $\mathbf{- 0 . 0 4 3}$ & $\mathbf{- 0 . 0 3 3}$ & $\mathbf{- 0 . 0 6 2}$ & $\mathbf{- 0 . 0 3 3}$ \\
& $(0.004)$ & $(0.005)$ & $(0.007)$ & $(0.006)$ \\
N & 36,566 & 15,952 & 17,478 & 10,858 \\
\hline 2nd Quartile of Admission Rate & $\mathbf{- 0 . 0 1 6}$ & $\mathbf{- 0 . 0 1 4}$ & -0.014 & $\mathbf{- 0 . 0 2 7}$ \\
& $(0.005)$ & $(0.005)$ & $(0.009)$ & $(0.007)$ \\
N & 32,863 & 23,190 & 14,400 & 9,617 \\
\hline 3rd Quartile of Admission Rate & 0.012 & 0.007 & 0.024 & -0.001 \\
& $(0.007)$ & $(0.008)$ & $(0.015)$ & $(0.011)$ \\
N & 25,957 & 14,506 & 11,943 & 7,592 \\
\hline 4th Quartile of Admission Rate & 0.012 & 0.002 & 0.004 & 0.015 \\
& $(0.008)$ & $(0.015)$ & $(0.012)$ & $(0.015)$ \\
N & 19,587 & 4,347 & 8,383 & 6,914 \\
\hline \hline
\end{tabular}

Note: Each coefficient comes from a separate regression. Standard errors allow for clustering at the applicant level.

Bolded coefficients are statistically significant at the $1 \%$ level. All specifications control for 'Maturita' test scores, secondary school type and average success rate, and university subject of study. The top (bottom) ability group consists of applicants with the math and/or the Czech test scores above (below) the 75th (25th) percentile. 
Table 4: Matching: 'Average Treatment on the Treated' of being Female in University Admission

\begin{tabular}{lcccc}
\hline \hline University Programs & All & 'Gender Balanced' & All & All \\
Applicants & All & All & Top Ability & Bottom Ability \\
& $(4)$ & $(4)$ & $(5)$ & $(6)$ \\
\hline 1st Quartile of Admission Rate & $\mathbf{- 0 . 0 4 5}$ & $\mathbf{- 0 . 0 3 3}$ & $\mathbf{- 0 . 0 6 5}$ & -0.007 \\
& $(0.006)$ & $(0.008)$ & $(0.009)$ & $(0.007)$ \\
N & 23,094 & 13,482 & 11,110 & 6,464 \\
\hline 2nd Quartile of Admission Rate & $\mathbf{- 0 . 0 3 1}$ & -0.021 & $\mathbf{- 0 . 0 3 9}$ & 0.008 \\
& $(0.010)$ & $(0.011)$ & $(0.012)$ & $(0.008)$ \\
N & 23,034 & 18,026 & 10,194 & 6,606 \\
\hline 3rd Quartile of Admission Rate & $\mathbf{- 0 . 0 2 6}$ & 0.005 & $\mathbf{- 0 . 0 3 1}$ & -0.021 \\
& $(0.007)$ & $(0.014)$ & $(0.010)$ & $(0.011)$ \\
N & 25,943 & 11,360 & 11,934 & 7,586 \\
\hline 4th Quartile of Admission Rate & 0.011 & 0.006 & -0.008 & 0.040 \\
& $(0.010)$ & $(0.019)$ & $(0.014)$ & $(0.021)$ \\
N & 19,587 & 3,568 & 8,383 & 6,912 \\
\hline \hline
\end{tabular}

Note: Each coefficient comes from a separate estimation. Standard errors allow for clustering at the applicant level.

Bolded coefficients are statistically significant at the $1 \%$ level. All specifications control for 'Maturita' test scores, secondary school type and average success rate, and university subject of study. The top (bottom) ability group consists of applicants with the math and/or the Czech test scores above (below) the 75th (25th) percentile. 
Table 5: School-Admission-Rate Coefficients from Fixed-Effect Admission Regressions

\begin{tabular}{|c|c|c|}
\hline Applicants & Men & Women \\
\hline \multirow[t]{2}{*}{ All 'Gender Balanced' Programs } & 0.998 & 1.263 \\
\hline & $(0.089)$ & $(0.099)$ \\
\hline Number of Applications & 15,206 & 23,311 \\
\hline Number of Fixed Effects & 6,881 & 11,146 \\
\hline \multirow[t]{2}{*}{ 'Gender Balanced' Programs below Median Admission Rate } & 1.126 & 1.499 \\
\hline & $(0.233)$ & $(0.204)$ \\
\hline Number of Applications & 10,656 & 16,259 \\
\hline Number of Fixed Effects & 5,916 & 9,066 \\
\hline \multirow{2}{*}{ 'Gender Balanced' Programs above Median Admission Rate } & 0.416 & 0.731 \\
\hline & $(0.193)$ & $(0.297)$ \\
\hline Number of Applications & 4,550 & 7,052 \\
\hline Number of Fixed Effects & 3,412 & 5,364 \\
\hline
\end{tabular}

Note: Each coefficient comes from a separate regression. Standard errors allow for clustering at the applicant level. Bolded coefficients are statistically significant at the $5 \%$ level. All specifications control for a person-school-type fixed effect. School type corresponds to eight types of university subject of study. The all-school median admission rate is 0.28 . 


\section{Appendix: Data Flow Chart}

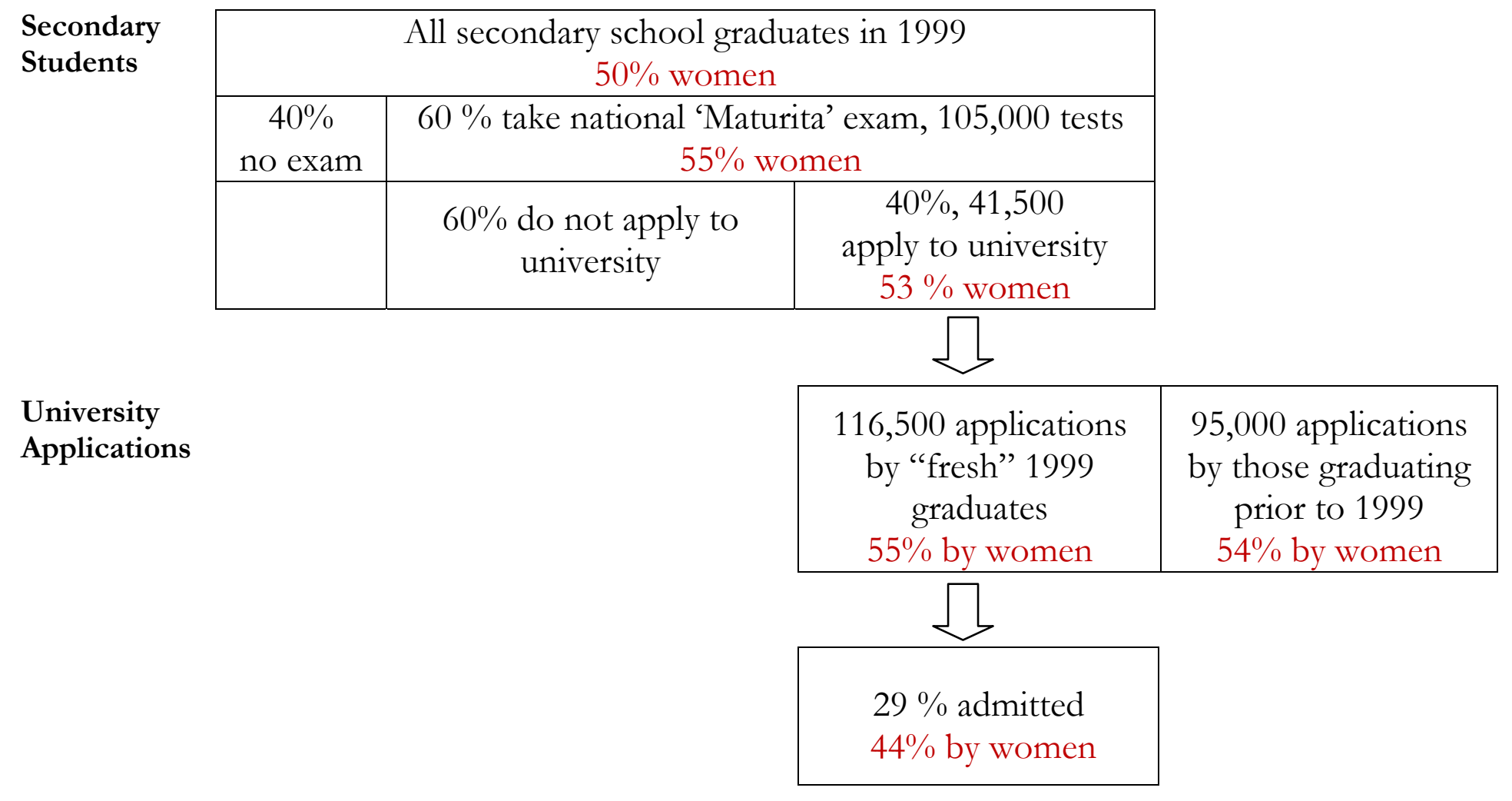


Individual researchers, as well as the on-line and printed versions of the CERGE-EI Working Papers (including their dissemination) were supported from the following institutional grants:

- Economic Aspects of EU and EMU Entry [Ekonomické aspekty vstupu do Evropské unie a Evropské měnové unie], No. AVOZ70850503, (2005-2010);

- Economic Impact of European Integration on the Czech Republic [Ekonomické dopady evropské integrace na ČR], No. MSM0021620846, (2005-2011);

Specific research support and/or other grants the researchers/publications benefited from are acknowledged at the beginning of the Paper.

(c) Štěpán Jurajda, Daniel Münich, 2008.

All rights reserved. No part of this publication may be reproduced, stored in a retrieval system or transmitted in any form or by any means, electronic, mechanical or photocopying, recording, or otherwise without the prior permission of the publisher.

Published by

Charles University in Prague, Center for Economic Research and Graduate Education (CERGE) and

Economics Institute ASCR, v. v. i. (EI)

CERGE-El, Politických vězňŭ 7, 11121 Prague 1, tel.: +420 224005 153, Czech Republic.

Printed by CERGE-EI, Prague

Subscription: CERGE-EI homepage: http://www.cerge-ei.cz

Editors: Directors of CERGE and EI

Managing editors: Deputy Directors for Research of CERGE and EI

ISSN 1211-3298

ISBN 978-80-7343-171-6 (Univerzita Karlova. Centrum pro ekonomický výzkum

a doktorské studium)

ISBN 978-80-7344-160-9 (Národohospodářský ústav AV ČR, v. v. i.) 
CERGE-EI

P.O.BOX 882

Politických vězňů 7

11121 Praha 1

Czech Republic http://www.cerge-ei.cz 